\title{
Absorption of zinc from lupin (Lupinus angustifolius)-based foods
}

\author{
BY D. S. PETTERSON \\ Department of Agriculture, South Perth, Western Australia 6151, Australia \\ AND B. SANDSTRÖM \\ Research Department of Human Nutrition, Royal Veterinary and Agricultural University, \\ Copenhagen, Denmark \\ AND Å. CEDERBLAD \\ Department of Radiation Physics, Sahlgrenska Hospital, University of Gothenburg, \\ Gothenburg, Sweden
}

(Received 20 December 1993 - Revised 13 April 1994 - Accepted 26 April 1994)

\begin{abstract}
The absorption of $\mathrm{Zn}$ from a lupin (Lupinus angustifolius) milk fortified with $\mathrm{Ca}$, a bread containing lupin flour $(230 \mathrm{~g} / \mathrm{kg})$, a sauce containing lupin flour and a sauce containing a lupin-protein isolate was determined in humans by measuring the whole-body retention of radioisotope from meals labelled with $0.02 \mathrm{MBq}{ }^{65} \mathrm{Zn}$, allowing for endogenous excretion of $\mathrm{Zn}$, after $14 \mathrm{~d}$. The absorption of $\mathrm{Zn}$ from the Caenriched milk (16.2\%) and the bread made with lupin flour (27.0\%) was similar to literature figures for comparable soya-bean products. The absorption from composite meals made with lupin flour (28-2\%) and protein isolate $(\mathbf{3 2 \cdot 7} \%$ ) was significantly higher than that reported for comparable soya-bean products. In a second experiment the absorption of $\mathrm{Zn}$ from a lupin-milk base and a soya-bean-milk base was compared with that from Ca-supplemented bases. The absorption of $\mathrm{Zn}$ from the lupin-milk base $(26.3 \%)$ was significantly higher than from the soya-bean-milk base $(17.6 \%)$, and neither was significantly altered by the addition of $\mathrm{Ca}$. Overall the absorption of $\mathrm{Zn}$ from lupin-protein foods was found to be higher than from comparable soya-bean products. Lupin milk could be an attractive alternative to soya-bean milk for infant formulas.
\end{abstract}

Zinc bioavailability: Lupins

Two species of lupin, Lupinus albus in the Mediterranean basin and L. mutabilis in the Andean highlands, have been cultivated for seed for over 2000 years (Gladstones, 1982). The extent of use of these seeds was greatly restricted by the high alkaloid content of the seed, often more than $20 \mathrm{~g} / \mathrm{kg}$. Low-alkaloid genes were discovered early this century in $L$. luteus and L. angustifolius and since then there have been great reductions in the alkaloid content of lupin seed through plant breeding programs. This has been contiguous with improved agronomic characteristics, especially for L. angustifolius in Australia (Gladstones, 1977,1982 ). Lupin seed is now a major crop in Western Australia with annual production of about 1 million tonnes: about $40 \%$ of this is retained on-farm for summer feeding of livestock and the remainder sold, to be used mostly in formulations for intensive animal industries. Only a few thousand tonnes are used for human consumption; however, there is increasing interest in this area (Kyle et al. 1991). The most obvious uses would be as an alternative to the soya bean and to other grain legumes. One of the advantages lupin seed offers over these commodities is the low content of antinutritive factors; typically they 
contain no detectable lectins, $0.14 \mathrm{mg}$ trypsin inhibitors/g and $4.4 \mathrm{mg}$ phytate/g (Horton et al. 1990).

The bioavailability of minerals, i.e. the absorption and utilization of the amounts present in the diet, depends on the chemical form of the element and the presence of other food components which may inhibit or stimulate absorption. In animal models the overall effects of a food component on bioavailability can be measured, e.g. by changes in growth rate or the mineral concentration of target tissues. In humans absorption can be estimated by isotope techniques while there is limited access to tissues that could mirror the overall bioavailability. For most elements, however, absorption is the major determinant of bioavailability. Phytate has been found to be a strong inhibitor of $\mathrm{Zn}$ absorption in man (Lönnerdal et al. 1984; Turnlund et al. 1984).

It is important to learn whether the low level of phytate in lupins will mean a higher absorption of minerals by humans. There are data showing that phytate alone is not the sole determinant of mineral absorption from grains and that the ( $\mathrm{Ca} \times$ phytate): $\mathrm{Zn}$ ratios (Davies \& Reid, 1979), and these ratios in relation to energy content of the diet (Gibson et al. 1991) and mineral concentration (Sandström, 1992) can serve as indicators. The present study investigated the absorption of $\mathrm{Zn}$ by humans from various lupin-containing meals, and compared the absorption from lupin- and soya-bean-milk bases with and without added $\mathrm{Ca}$.

\section{MATERIALS AND METHODS}

Healthy men and women volunteers were given written and oral information about the aims of the study. The study was approved by the Research Ethical Committee and the Isotope Committee of Sahlgren's Hospital, Gothenburg.

There were twelve female and twenty male volunteers of mean age 26 (SD 6, range 19-37) years. Their body mass index values were 22.3 (SD 4.4 , range $19 \cdot 0-32.9) \mathrm{kg} / \mathrm{m}^{2}$ : four subjects had an index above 25 . Serum $\mathrm{Zn}$ concentrations were 15.8 (SD 2.4) $\mu \mathrm{mol} / 1$, with the range 12.9-23.3 $\mu \mathrm{mol} / 1$ being within the hospital's reference range for young subjects.

In the first experiment, three lupin-based products were tested. Four meals were prepared: (1) a $450 \mathrm{~g}$ serving of lupin milk; (2) three buns, net weight $87 \mathrm{~g}$, made with a 3:10 mixture of lupin flour and wheat flour, served with $10 \mathrm{~g}$ butter and $200 \mathrm{~g}$ cow's milk ( $5 \mathrm{~g}$ fat/1); (3) a vegetarian sauce, net weight $250 \mathrm{~g}$, based on $55 \mathrm{~g}$ lupin-protein isolate served with $40 \mathrm{~g}$ rice and water; (4) a vegetarian sauce, net weight $250 \mathrm{~g}$, based on $20 \mathrm{~g}$ lupin-protein isolate served with $\mathbf{4 0} \mathrm{g}$ rice and water. The composition of each meal was as close as possible to that of soya-bean-protein-based meals used in earlier studies (Sandström et al. 1983, 1987). Each meal was labelled with $0.02 \mathrm{MBq}{ }^{65} \mathrm{Zn}$ during preparation and allowed to equilibrate overnight before being offered to the subjects. Each subject was randomly served two of the test meals, a minimum of 6 weeks apart. The milk and the buns were served after an overnight fast and the sauces at lunch time, $4 \mathrm{~h}$ after consumption of a standardized breakfast (Arvidsson et al. 1978). No food or drink was allowed for $3 \mathrm{~h}$ after ingestion of the labelled meals. The absorption of $\mathrm{Zn}$ was determined by measuring the whole-body retention of ${ }^{65} \mathrm{Zn}$ after $14 \mathrm{~d}$ and correcting for endogenous excretion of $\mathrm{Zn}$ (Arvidsson et al. 1978).

In the second experiment, two lupin milks and two soya-bean milks were tested. Four meals were prepared: (1) a $250 \mathrm{~g}$ serving of lupin-milk base; (2) a $250 \mathrm{~g}$ serving of lupinmilk base fortified with Ca (approximately $45 \mathrm{mmol}$ ); (3) a $250 \mathrm{~g}$ serving of soya-bean-milk base; and (4) a $250 \mathrm{~g}$ serving of soya-bean-milk base fortified with Ca (approximately $45 \mathrm{mmol}$ ). Labelling of the meals and the test routines was as in the first experiment.

The lupin milk was prepared from kernels of $L$. angustifolius (cv. Danja). The cotyledons were hammer-milled twice, first with a $3.2 \mathrm{~mm}$ screen and then with a $1.6 \mathrm{~mm}$ screen. The 
'flour' was diluted 12-fold with water and the slurry passed through a laboratory-scale Fryma carborundum stone colloid mill (Fryma-Maschinen AG, Reinfelden, Switzerland). Sucrose $(29 \mathrm{~g} / 1)$ and $\mathrm{CaCl}_{2}(2 \mathrm{~g} / 1)$ were blended into the suspension and the $\mathrm{pH}$ adjusted to 6.0 by adding $\mathrm{Na}_{2} \mathrm{CO}_{3}$. The material was spray-dried in a Niro Minor (A/S Niro Atomizer, Copenhagen, Denmark), inlet temperature $190^{\circ}$, outlet $90^{\circ}$, vacuum packed and reconstituted as required.

The lupin-milk base for the second experiment was prepared at Alfa-level South East Asia Pte, Jurong, Singapore. Dehulled lupin seed, L. angustifolius cv. Gungurru, was soaked in five volumes of $\mathrm{NaHCO}_{3}(5 \mathrm{~g} / \mathrm{l})$ and glucono- $\delta$-lactone $(10 \mathrm{~g} / \mathrm{l})$ for $1 \mathrm{~h}$ and drained. The soaked beans were then fed into a Fryma perforated disk mill, $4 \mathrm{~mm}$ holes, with 3.5 volumes water and about 1 volume $\mathrm{NaOH}(5 \mathrm{~g} / 1)$ to maintain $\mathrm{pH}$ (approximately $8 \cdot 5)$. The slurry then passed through a Fryma colloid mill, a heat treatment $\left(90-92^{\circ}\right.$ for $200 \mathrm{~s}$ ), followed by rapid cooling to $62^{\circ}$ and deaeration. The slurry next passed through a centrifugal decanter and the protein-rich fraction was cooled to $20^{\circ}$. This fraction, the milk base, was brought to $\mathrm{pH} 6.5$ before sterilizing under UHT and packing into $250-\mathrm{ml}$ tetrabriks.

The soya-bean-milk base was prepared from whole soya beans, Glycine max, Canadian No. 1 Yellow, after soaking in water and then following the procedure for the lupin-milk base.

Lupin kernel flour was prepared by stone-milling dehulled lupin seed, and passing the product through a $420 \mu \mathrm{m}$ screen to remove any grits.

Lupin-protein isolate was prepared from lupin flour by solubilizing protein at $\mathrm{pH} 9 \cdot 0$, using $2 \mathrm{M}-\mathrm{KOH}$, and then precipitating the protein fraction from the solubles by adjusting the $\mathrm{pH}$ to 4.2 with $1 \mathrm{M}-\mathrm{HCl}$. After centrifugation the isolated protein was brought to $\mathrm{pH} 6.5$ and then freeze-dried.

Mineral analyses were as described by Sandström et al. (1987). NBS Liver No. 1577a was used for the reference standards. The coefficients of variation (\%) were: Ca 7·3, Fe 5·3, $\mathrm{Mg}$ $9 \cdot 6, \mathrm{Zn} 5 \cdot 3, \mathrm{P} 4 \cdot 2$. $\mathrm{N}$ analysis was by a micro-Kjeldahl technique (Technicon Instruments Co. Ltd., London). Phytate was by the method of Davies \& Reid (1979). Details of the meals used are shown in Tables 1 and 2.

\section{RESULTS}

The concentrations of $\mathrm{N}$, minerals and phytic acid in the test meals for the two experiments are shown in Table 1, together with the absorption of $\mathrm{Zn}$ from each of the meals, and the phytate: $\mathrm{Zn}$ and (phytate $\times \mathrm{Ca}$ ): $\mathrm{Zn}$ ratios. A comparison between the absorption of $\mathrm{Zn}$ from these meals and similar soya-bean preparations, determined in earlier studies, is shown in Table 2.

The absorption of $\mathrm{Zn}$ from the lupin milk and bread made with lupin flour was similar to that from comparable soya-bean products. However, the absorption from the flour 'sauce' meal, $28.2 \%$, and the isolate 'sauce' meal, $32 \cdot 7 \%$, were both significantly higher than the earlier values obtained for similar soya-bean preparations, 14.0 and $20.9 \%$ respectively.

The absorption of $\mathrm{Zn}$ from the lupin-milk base, $26 \cdot 3 \%$, was unaffected by adding $\mathrm{Ca}$ $(26.5 \%)$. Similarly the absorption of $\mathrm{Zn}$ from the soya-bean-milk base, $17.6 \%$, was not affected by adding $\mathrm{Ca}(15 \cdot 1 \%)$.

\section{DISCUSSION}

The fractional absorption of $\mathrm{Zn}$ from lupin flour and isolate 'sauces' was higher than from comparable soya-bean products, even though the phytate: $\mathrm{Zn}$ molar ratios were similar. A phytate: $\mathrm{Zn}$ ratio higher than 10 would be expected to reduce absorption to below $20 \%$ for 


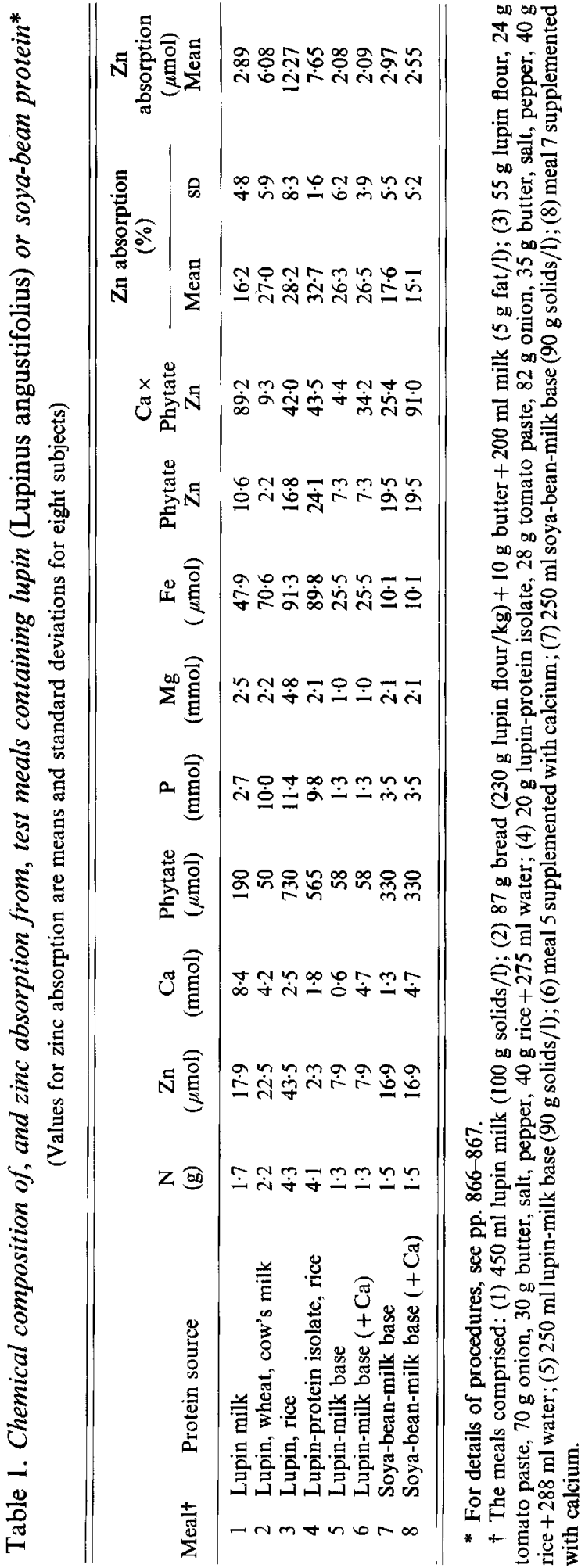


Table 2. Percentage zinc absorption from test meals containing lupin (Lupinus angustifolius) or soya-bean protein, in human subjects

(Mean values and standard deviations)

\begin{tabular}{|c|c|c|c|c|c|c|}
\hline \multirow{2}{*}{$\begin{array}{l}\text { Test meal } \\
\text { base }\end{array}$} & \multirow{2}{*}{$\begin{array}{c}\mathrm{Zn} \\
(\mu \mathrm{mol})\end{array}$} & \multirow{2}{*}{$\begin{array}{l}\mathrm{N} \\
(\mathrm{g})\end{array}$} & \multirow{2}{*}{$\underset{(\mathrm{mmol})}{\mathrm{Ca}}$} & \multirow{2}{*}{$\begin{array}{l}\text { Phytate } \\
(\mu \mathrm{mol})\end{array}$} & \multicolumn{2}{|c|}{$\begin{array}{c}\text { Zn absorption } \\
(\%)\end{array}$} \\
\hline & & & & & Mean & SD \\
\hline Lupin milk* & 18 & 1.7 & $8 \cdot 4$ & 190 & $16 \cdot 2$ & $4 \cdot 8$ \\
\hline Soya-bean formula $\dagger$ & 26 & $1 \cdot 4$ & $6 \cdot 2$ & 200 & $14 \cdot 0$ & $1 \cdot 0$ \\
\hline Bread (lupin flour)* & 23 & $2 \cdot 2$ & $4 \cdot 2$ & 50 & $27 \cdot 0$ & $5 \cdot 9$ \\
\hline Bread (soya-bean flour) $\$$ & 26 & $2 \cdot 4$ & 7.6 & 140 & $24 \cdot 2$ & $7 \cdot 7$ \\
\hline Lupin flour 'sauce'* & 43 & $4 \cdot 3$ & $2 \cdot 5$ & 730 & $28 \cdot 2$ & $8 \cdot 3$ \\
\hline Soya-bean flour 'sauce' & 37 & $3 \cdot 2$ & $4 \cdot 3$ & 880 & 14.0 & $2 \cdot 8$ \\
\hline Lupin isolate 'sauce'* & 23 & $4 \cdot 1$ & 1.8 & 565 & $32 \cdot 7$ & $1 \cdot 6$ \\
\hline Soya-bean isolate "sauce' $\ddagger$ & 18 & $3 \cdot 5$ & $2 \cdot 5$ & 510 & $20 \cdot 9$ & 5.9 \\
\hline
\end{tabular}

* Present paper.

$\dagger$ Values from Sandström et al. (1983).

¥ Values from Sandström et al. (1987).

humans (Ellis et al. 1987; Sandström et al. 1987) and ratios higher than 15 reduce the absorption from soya-beans by rats (Lo et al. 1981). The present results for lupins suggest that phytate alone is not the factor limiting $\mathrm{Zn}$ absorption.

It has been shown for rats that $\mathrm{Ca}$ exacerbates the negative effect of phytate on $\mathrm{Zn}$ absorption from soya-bean-protein meals (Forbes et al. 1983). (Phytate $\times \mathrm{Ca}$ ): Zn molar ratios above 91 , adjusted for energy intake, appear to be of potential concern for humans (Gibson et al. 1991). This has, however, not been confirmed in human studies. In the present study we found no effect of adding $\mathrm{Ca}$ to either lupin or soya-bean milks on $\mathrm{Zn}$ absorption. This finding supports the earlier observation of Lönnerdal et al. (1984) who found that adding approximately $800 \mathrm{mg} \mathrm{Ca} / 1$ soya-bean-protein isolate formula (phytate: $\mathrm{Zn}$ ratio 6:1) had no significant effect on $\mathrm{Zn}$ absorption. A positive effect on $\mathrm{Zn}$ absorption of milk, a high-Ca food, to a phytate-containing meal has earlier been reported (Sandström et al. 1980). The levels of Ca used in animal experiments are in general higher than in human diets so that might explain the different results. At lower levels $\mathrm{Ca}$ might block the phytate and render $\mathrm{Zn}$ free to be absorbed. Thus within the range of $\mathrm{Ca}$ intake that can be found in human diets the phytate- $\mathrm{Zn}-\mathrm{Ca}$ interaction does not seem to be of nutritional significance.

The observed differences in fractional absorption of $\mathrm{Zn}$ from the lupin milk $(16 \cdot 2 \%)$ and the milk base (26.3\%) cannot be explained in terms of phytate: $\mathrm{Zn}$ ratios as the fractional absorption was higher than could be expected from the rather small differences in ratio $(10 \cdot 6$ v. $7 \cdot 3$ ). The (phytate $\times \mathrm{Ca}): \mathrm{Zn}$ ratio does not seem to be a good predictor either, as similar absorption figures were observed from meals differing in this ratio from 4.4 to 42 . Three factors could have contributed to the difference observed between the lupin milk and the base. First, and probably the most important one, there was about a twofold difference in the amount of $\mathrm{Zn}$ consumed. A recent review by Sandström (1992) showed that the fractional absorption of $\mathrm{Zn}$ decreases with increasing amount ingested. Second, the lupin milk was spray-dried and reconstituted, and this may have resulted in more stable complexes being formed between the divalent ions and protein and/or any fibre present. Third, the lupin milk was extracted at about neutral $\mathrm{pH}$ and the final $\mathrm{pH}$ adjusted to 6.0 whereas the lupin-milk base was prepared by an alkaline extraction followed by 
neutralization to $\mathrm{pH}$ 6.5. Different protein profiles with different digestibility or mineral and phytate binding properties might have resulted from these procedures. A lower smallintestinal digestibility of soya-bean protein compared with animal protein has been observed in studies of human ileostomized subjects (Sandström et al. 1986). The binding of phytic acid to glycinin, the major protein of soya beans, is highly $\mathrm{pH}$-dependent (Okubo et al. 1976) and it is reasonable to assume that this is also the case for lupin proteins.

The absorption of $\mathrm{Zn}$ from the lupin-milk base, $26 \cdot 3$ (SD 6.2) \%, was similar to reported values for cow's milk, 28 (SD 15) \%, and infant formulas in studies using the same radionuclide technique and the same amount of formula or test meal (Sandström et al. 1983) as in the present study. The values are also similar to those of Egan et al. (1991) using a cow's milk formula intrinsically labelled with stable $\mathrm{Zn}$ isotopes $(26.7 \%)$. Studies in infants using stable isotopes have found 16-40\% absorption from an infant formula, with the higher absorption at a low $\mathrm{Zn}$ intake (Ziegler et al. 1989). From a term formula given to very-low-birth-weight infants $23.6 \%$ was absorbed (Ehrenkrantz et al. 1989). This high absorption of $\mathrm{Zn}$, high protein content together with the low allergenicity of lupin proteins (Gross, 1988) might make lupin milk an attractive alternative to soya-bean milk for infant formulas and in cases where intolerance of or allergy to cow's milk occurs. With the low phytate content of the lupin-milk base the absorption of other elements besides $\mathrm{Zn}$ and $\mathrm{Ca}$ can also be expected to be high. Addition of $\mathrm{Zn}$ to this base will most likely result in a larger amount of $\mathrm{Zn}$ being absorbed and hence further improve the nutritional value of the product.

We thank Annette Almgren for technical assistance. This project was funded by the Grain Research Committee of Western Australia, the Grains Research Development Corporation, Australia and the Danish Board for Agricultural and Veterinary Research.

\section{REFERENCES}

Arvidsson, B., Cederblad, Å, Björn-Rasmussen, E. \& Sandström, B. (1978). A radionuclide technique for studies of zinc absorption in man. International Journal of Nuclear Medicine and Biology 5, 104-109.

Davies, N. T. \& Reid, H. (1979). An evaluation of the phytate, zinc, copper, iron and manganese contents of, and $\mathrm{Zn}$ absorption from, soya-based textured-vegetable-protein meat-substitutes or meat-extenders. British Journal of Nutrition 41, 579-589.

Egan, C. B., Smith, F. G., Houk, R. S. \& Serfass, R. E. (1991). Zinc absorption in women : comparison of intrinsic and extrinsic stable-isotope labels. American Journal of Clinical Nutrition 53, 547-553.

Ehrenkranz, R. A., Gettner, P. A., Nelli, C. M., Sherwonit, E. A., Williams, J. E., Ting, B. T. G. \& Janghorbani, M. (1989). Zinc and copper nutritional studies in very low birth weight infants: comparison of stable isotopic extrinsic tag and chemical balance methods. Pediatric Research 26, 298-307.

Ellis, R., Kelsay, J. L., Reynolds, R. D., Morris, E. R., Moser, P. B. \& Frazier, C. W. (1987). Phytate:zinc and phytate $\times$ calcium:zinc millimolar ratios in self-selected diets of Americans, Asian Indians, and Nepalese. Journal of the American Dietetic Association 87, 1043-1047.

Forbes, R. M., Erdman, J. W. Jr, Parker, H. M., Kondo, H. M. \& Ketelsen, S. M. (1983). Bioavailability of zinc in coagulated soy protein (tofu) to rats and effect of dietary calcium at a constant phytate:zinc ratio. Journal of Nutrition 113, 205-210.

Gibson, R. S., Smit Vanderkooy, P. D. \& Thompson, L. (1991). Dietary phytate $\times$ calcium/zinc millimolar ratios and zinc nutriture in some Ontario preschool children. Biological Trace Element Research 30, 87-94.

Gladstones, J. S. (1977). The Narrow-Leafed Lupin in Western Australia. Western Australia Department of Agriculture Bulletin 3990. South Perth: Government Printer.

Gladstones, J. S. (1982). Breeding the first modern crop lupins. Journal of Agriculture, Western Australia 23, 70-72.

Gross, R. (1988). Lupins in human nutrition. In Proceedings of the Fifth International Lupin Conference, Poznan, Poland, pp. 55-63 [T. Twardowski, editor]. Poznan: PWRIL.

Horton, J., Petterson, D. S. \& Mackintosh, J. B. (1990). The Chemical Composition and Nutritive Value of Grain Legumes Grown in Australia. Canberra: Grain Legumes Research Council.

Kyle, W. S. A., Petterson, D. S. \& Evans, A. J. (1991). The use of lupins in Asian food products. In Food Ingredients Asia, pp. 176-179. Maarssen: Expoconsult Publishers.

Lo, G. S., Settle, S. L., Steinke, F. H. \& Hopkins, D. T. (1981). Effect of phytate:zinc molar ratio and isolated soybean protein on zinc bioavailability. Journal of Nutrition 111, 2223-2235. 
Lönnerdal, B., Cederblad, Å., Davidsson, L. \& Sandström, B. (1984). The effect of individual components of soy formula and cow's milk formula on zinc bioavailability. American Journal of Clinical Nutrition 40, 1064-1070.

Okubo, K., Myers, D. V. \& Iacobucci, G. A. (1976). Binding of phytic acid to glycinin. Cereal Chemistry 53, 513-524.

Sandström, B. (1992). Dose dependence of zinc and manganese absorption in man. Proceedings of the Nutrition Society 51, 211-218.

Sandström, B., Andersson, H., Kivistö, B. \& Sandberg, A. S. (1986). Apparent small intestinal absorption of nitrogen and minerals from soy and meat-protein-based diets. A study on human ileostomy subjects. Journal of Nutrition 116, 2209-2218.

Sandström, B., Arviddson, B., Cederblad, Å. \& Björn-Rasmussen, E. (1980). Zinc absorption from composite meals. 1. The significance of wheat extraction rate, zinc, calcium and protein content in meals based on bread. American Journal of Clinical Nutrition 33, 739-745.

Sandström, B., Cederblad, А. \& Lönnerdal, B. (1983). Zinc absorption from human milk, cow's milk and infant formulas. American Journal of Diseases of Children 137, 726-729.

Sandström, B., Kivistö, B. \& Cederblad, Å. (1987). Absorption of zinc from soy protein meals in humans. Journal of Nutrition 117, 321-327.

Turnlund, J. R., King, J. C., Keyes, W. R., Gong, B. \& Michel, M. C. (1984). A stable isotope study of zinc absorption in young men: effects of phytate and $\alpha$-cellulose. American Journal of Clinical Nutrition 40 , 1071-1077.

Ziegler, E. E., Serfass, R. E., Nelson, S. E., Figueroa-Colon, R., Edwards, B. B., Houk, R. S. \& Thompson, J. J. (1989). Effect of low zinc intake on absorption and excretion of zinc by infants studied with ${ }^{70} \mathrm{Zn}$ as extrinsic tag. Journal of Nutrition 119, 1647-1653. 